\title{
Internalisasi Nilai Luhur Ahlu Sunnah wal Jama'ah Bagi Pengembangan Karakter kebangsaan Di Perguruan Tinggi
}

\author{
Umi Musaropah $^{1}$, Muhamad Mahali ${ }^{2}$, Daluti Delimanugari ${ }^{3}$,Agus Suprianto ${ }^{4}$, \\ Taufik Nugroho ${ }^{5 *}$ \\ ${ }^{1234}$ STAI Yogyakarta Wonosari, ${ }^{5}$ Universitas Cokroaminoto Yogyakarta \\ *Penulis Koresponden, email: taufikn325@gmail.com
}

\begin{abstract}
Abstrak
Penelitian deskriptif analitis ini bermaksud melihat pembentukan karakter kebangsaan dikondisikan dalam miliu belajar yang mendukung di PTKI berciri khas organisasi kemasyarakatan Nahdlatul Ulama yang berpegang teguh pada nilai luhur Ahlu Sunnah wal Jamaah (Aswaja). Utamanya, Penanaman kebangsaan yang berciri khas keagamaan dalam tridarma perguruan tinggi yang bisa dirasakan bagi mahasiswa sebagai pelajar berusia dewasa. Penelitian dibatasi pada proses Internalisasi mata kuliah penciri yang bermuatan kearifan lokal, atau juga dikenal dengan ke-NU-an, di Sekolah Tinggi Agama Islam Yogyakarta (STAIYO) Wonosari. Studi kasus dilakukan secara kualititatif. Satelah data hasil observasi partisipatif, wawancara mendalam, dan dokumentasi dianalisis maka disiumpulkan bahwa tingkat partisipasi mahasiswa dan seluruh sivitas akademika STAIYO sangatlah tinggi. Hal ini disebabkan karena mereka menyadari bahwa di kemudian hari mereka akan menjadi tokoh masyarakat yang harus mengayomi dalam nalar agama berkebangsaan NKRI.
\end{abstract}

Kata Kunci: Internalisasi, Ahlu Sunnah wal Jamaah, kebangsaan, PTKI

\begin{abstract}
This analytical descriptive study intends to see the formation of national characteristics conditioned in supporting learning milliu at PTKI characterized by the Nahdlatul Ulama organization that adheres to the noble values of Ahlu Sunnah wal Jamaah (Aswaja). Mainly, the cultivation of nationalism which is characterized by religion in the tridarma of higher education that can be felt by students as adult students. The research is limited to the process of internalizing characteristic courses that contain local wisdom, or also known as NU-ness, at the Yogyakarta Islamic College (STAIYO) Wonosari. Case studies are conducted qualitatively. After the data from participatory observation, in-depth interviews, and documentation were analyzed, it was concluded that the level of participation of students and all STAIYO academicians was very high. This is because they realize that in the future they will become community leaders who have to protect the religious reasoning as NKRI.
\end{abstract}

Keywords: cultivation, Ahlu Sunnah wal Jamaah, national characteristics, PTKI

This is an open access article under the C(-BY-SA license c) (1) (-) 
Umi Musaropah, Muhamad Mahali, Daluti Delimanugari,

Agus Suprianto, Taufik Nugroho

\section{Pendahuluan}

Pendidikan kemasyarakatan berkebangsaan di PT tidak menghendaki lebih banyak dari mahasiswa peserta didik, karena prinsip ini pada dasarnya sama dengan pelaksanaannya pada jenjang pendidikan yang lain. Perbedaannya pada mulai diterapkan perspektif andragogi dalam pendidikannya. Jenjang pendidikan ini memiliki keunggulan dalam persesuaiannya dengan pendidikan masyarakat usia dewasa yang mengarahkan pada pendidikan sepanjang hayat. Pendidikan yang tak membatasi ruang kelas dan kampus, tetapi melibatkan keluarga dan masyarakat secara langsung sebagai bagian dari kurikulumnya.

Kebangsaan pasca kemerdekaan Indonesia akan membentuk manusia yang memiliki rasa komitmen dan tanggungjawab untuk mengabdikan diri pada tanah air dalam nilai-nilai dasar keagamaan (Musaropah 2019). Semua itu telah terangkum dalam Pancasila menuju keadilan dan kesejahteraan pribadi, masyarakat local, nasional hingga global secara aktif. Rasa komitmen ini adalah, "keterikatan terhadap Tuhannya, diri sendiri dan keterikatan terhadap hak, harga diri, serta martabat orang lain, dan keterikatan terhadap terpeliharanya lingkungan hidup yang memberikan dampak besar terhadap kehidupan manusia." (Alfin dan Santoso 2013; Tim Penyusun 2010).

Dengan rujukan dari Lickona (2013), karakter ideal Mahasiswa PTKI yang berkomitmen terhadap kebangsaan adalah insan akademik yang menguasai pengetahuan, perasaan, dan tindakannya selalu dalam kerangka moralitas. Yang pertama memuat kesadaran moral, pengetahuan tentang nilainya termasuk penalaran dalam memutuskan penyelesaian. Moral kedua berisi; keyakinan diri, kepercayaan diri, tenggang rasa, kecintaan dalam kebaikan, pengendalian diri kuat, tawadu dalam kerendahan hati. Moral terakhir tentang bagaimana seseorang bertindak. Di situ ia harus memiliki kecakapan yang kompeten, cita-cita keinginan dan habit kebiasaan yang baik.

Moralitas kompleks demikian itu tidak bisa menciptakan manusia bekarakter kebangsaan yang belajar dalam ruang terbatas. Dinding kelas bukan batasan mutlak sehingga bisa seseorang bisa belajar moral secara luas hingga dalam pendampingan dari masyarakat sekitarnya. Pembentukan tiga 
moral ideal itu harus dikondisikan dalam miliu belajar yang mendukung untuk pembelajarannya. Lickona telah memberikan gambaran ringkas bagaimana semua lingkungan yang membelajarkan berhubungan dan berkaitan antar masing-masing komponen-komponen.(Tim Penyusun 2010)

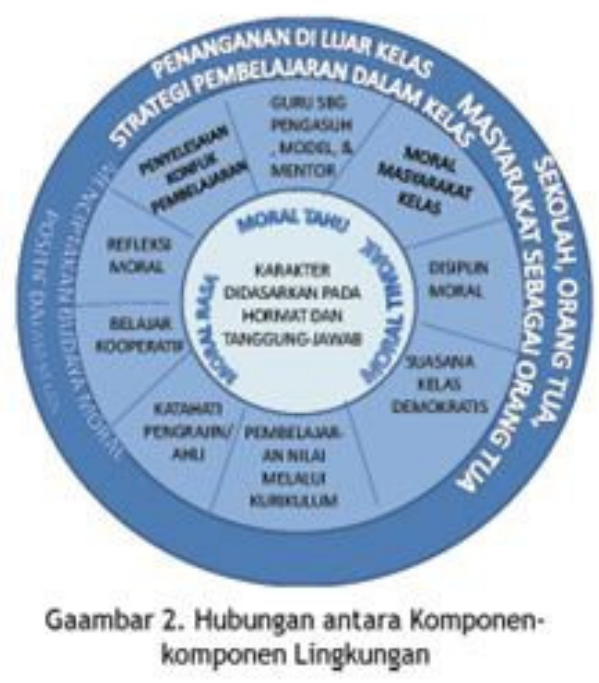

Tiga moral karakter tersebut telah dibiasakan dalam semua lingkungan dimana insan belajar bisa belajar secara nyaman dan menyenangkan guna pencapaian tujuan moral. Di situ mahasiwa yang belajar bisa membentuk diri untuk berpikir sebagai kewajiban diri (self- regulation), kritis, serta kreatif. Semua itu tercipta melalui kebiasaan berpikir mandiri. Habits of mind itu terbangun dari beberapa komponen sebagai berikut; kesadaran diri, perencanaan berawal dari evaluasi diri, dan perenungan untuk refleksi. lingkungan belajar kebangsaan yang demikian menjadikan PTKI hanya bertugas untuk menyediakan lingkungan belajar yang nyaman dan integratif dengan lingkungan yang lain. Masjid kampus pun menjadi unsur penting dalam membina sikap kebangsaan yang antisipatif terhadap radikalisme (Fauroni et al. 2019).

Agar pendidikan mampu mewujudkan karakteristik masyarakat berkebangsaan di atas, PT bisa melakukan beberapa langkah strategis.

1) Mendorong tumbuhnya benih kepedulian di luar lingkungan PT dengan menggunakan tokoh model yang inspiratif dan layanan masyarakat sebagai pusat kegiatan peserta didik belajar mengabdi dan memberikan layanan. 2) Penciptaan budaya moral positif di lingkungan kampus, mengembangkan 
Umi Musaropah, Muhamad Mahali, Daluti Delimanugari,

Agus Suprianto, Taufik Nugroho

lingkungan yang padu melalui kepemimpinan, kedisiplinan tinggi, terciptanya masyarakat kampus dengan rasa-menyatu, pemerintahan mahasiswa yang demokratik, mewujudkan anggota dewasa kampus yang bermoral, dan penyediaan kesempatan yang luas untuk menyalurkan kepeduliaan moral, sehingga tercipta keselarasan antara nilai-nilai yang diajarkan di ruang perkuliahan dan nilai-nilai yang mereka saksikan dan rasakan di luar ruang perkuliahan. 3) Merangkul orang tua mahasiswa dan masyarakat sebagai mitra dan pendidikan karakter, mendorong orang tua mahasiswa untuk menjadi guru moral yang pertama dan utama, dan menginformasikan secara terus-menerus berbagai cara menanamkan karakter di lingkungan rumah, masyarakat maupun kampus.(Alfin dan Santoso 2013; Tim Penyusun 2010)

\section{Metode Penelitian}

Penelitian deskriptif analitis ini bermaksud melihat bagaimana PTKI menanamkan kebangsaan yang berciri khas keagamaan dalam tridarma perguruan tinggi yang bisa dirasakan bagi mahasiswa sebagai pelajar berusia dewasa. Penelitian dibatasi pada proses Internalisasi mata kuliah penciri bermuatan local, Ahlu Sunnah wal Jamaah (Aswaja) atau juga dikenal dengan ke-NU-an, di Sekolah Tinggi Agama Islam Yogyakarta Wonosari. Studi kasus dilakukan secara kualititatif, dengan beberapa metode pengumpulan data primer, yaitu observasi partisipan, dokumentasi serta wawancara mendalam dengan informan terpilih.Triangulasi perpanjangan waktu dipilih dengan pengulangan metode pengumpulan data dan penelusuran sumber-sumber sekunder yang relevan. Data-data kemudian dianalisis untuk mendapatkan kesimpulan.

\section{Nilai-Nilai luhur Ahlu Sunnah Wal Jama'ah}

Visi STAIYO Gunung Kidul, "Terwujudnya Perguruan Tinggi yang Unggul dalam mencetak Pendidik Profesional dan berakhlakul karimah sebagai Guru Pendidikan Agama Islam (PAI)."(Syafiyana 2015; Tim STAIYO 2015) Visi demikian juga tidak bisa dilepaskan secara organisatoris dengan lembaga terkait dengan mata kuliah penciri PT. Struktur STAIYO dibanding berkaitan langsung dengan NU secara langsung, khususnya yang membawahi wilayah Gunung Kidul. Perkembangan tersebut diikuti dengan pengaturan kembali yayasan penyelenggaranya. Lembaga Pendidikan Maarif 
NU beralih menjadi Lajnah Perguruan Tinggi NU.(Syafiyana 2015; Tim STAIYO 2015)

Dengan cara demikian mata kuliah penciri dikenal dengan keNahdatul Ulama-an (ke-NU-an). Nama lainnya adalah Ahlu Sunnah wal Jama'ah (Aswaja). Mata kuliah itu menjadi pokok penting untuk menyebarkan dan menginternalisasi nilai-nilai penciri ke dalam mahasiswa. Ke-NU-an lebih bersifat sebagai kajian umum sebuah organisasi Islam. Dalam sejarah kurikulum STAIYO, penciri PTKIS ini memang masih baru. Pada program studi PAI mulai masuk pada Semester genap tahun 20152016.

Muatan mata kuliah Ke-NU-an perlu dijabarkan terlebih dahulu. Di situ kita menggali bagaimana relasi Islam dan kebangsaan bisa berkaitan membentuk tatanan masyarakat Indonesia. Penjelasan kemudian berupa implementasi pendidikan Islam kebangsaan yang ada di Aswaja dielaborasi lebih lanjut dalam TDPT, khususnya bagi mahasiswa.

Aswaja sangat kuat berpegang pada Mabadi Khaira Ummah (MKU) yang merupakan fondasi bagi pembentukan umat Islam menuju terbaik di dunia dan kahirat. Merekalah yang bertugas dengan dua pokok dalam urusan duniawi, penyeru kepada kebaikan dan pencegah keburukan (amr ma'ruf wa nahy munkar) (PP. LAKPESDAM NU 1992). Penugasan itu menjadi bagian utama dari misi NU karena dianggap mutlak dalam penopangan bagi perwujudan tatanan sosial Islami dalam visi pergerakan NU. Amar makruf adalah ajakan dan seruan kepada perbuatan baik, yaitu yang bermanfaat bagi kehidupan dunia akhirat. nahy munkar adalah kebalikannya, yaitu peringatan dan pencegahan dari segala sesuatu yang merugikan, merendahkan, dan merusak nilai-nilai kehidupan. Pemenuhan kedua tugas pokok menjamin pencapaian kebahagiaan lahir dan batin. Tugas itu menjadi prinsip dasar umat terbaik kemudian dikenal dengan MKU.

Sedangkan sebagian lainnya mengatakan bahwa umat terbaik tidak terbatas sahabat di zaman Nabi tetapi menunujuk kepada semua umat Islam pada setiap periode sepanjang syarat-syarat yang terkait dengan ayat tersebut terpenuhi yaitu, beriman dan berseru kepada kebaikan termasuk pencegahan 
Umi Musaropah, Muhamad Mahali, Daluti Delimanugari,

Agus Suprianto, Taufik Nugroho

umat dari keburukan. Ahli Tafsir Andalus bernama Qurtubi kemudian berkesimpulan bahwa predikat itu dapat diperoleh bagi umat Islam pada setiap periode bila tantangan yang dihadapinya sama seperti umat Islam pada periode pertama, yaitu bila ajaran Islam itu dianggap gharib (asing) seperti pada waktu datang pertama kalinya, orang-orang yang benar-benar beriman direndahkan dan perbuatan yang fasiq semakin subur. Dalam kondisi yang demikian dibutuhkan tampilnya suatu umat yang berkualitas dan tidak hanya memiliki keberanian tetapi juga memiliki kemampuan untuk mengatasinya. Umat seperti ini dinamakan umat terbaik yang bisa memunculkan beberapa periode sesuai dengan kemungkinan timbulnya keadaan seperti yang dikemukakan di atasnya.

Jika semula $M K U$ hanya memuat tiga butir nilai seperti telah disebut di atas, dua butir lagi perlu ditambahkan untuk mengantisipasi persoalan dan kebutuhan kontemporer. Kedua butir itu adalah al-'Adalah dan al-Istiqamah. Dengan demikian, $M K U$ pembawa lima butir nilai yang dapat pula disebut sebagai “Al-Mabadi Al-Khamsah”.(PP. LAKPESDAM NU 1992) As-Sidq

Kejujuran pada yang benar secara bersungguh dan terbuka. Di situ ada makan penyatuan dari kata dan tindakan, lisan dan kehendak akal. Apa yang diucapkan sama dengan yang di bathin. Jujur dalam ketegasan yang tidak ragu-ragu dalam ucapan dan tindakan, kalupun terjadi, kemunculannya dikarenakan ketidaksengajaan untuk merubah bukti fakta atau maksud penginformasian yang sesat. Dan tentu saja jujur pada diri sendiri. Termasuk dalam pengertian ini adalah jujur dalam bertransaksi menjauhi segala bentuk penipuan demi mengejar keuntungan. kejujuran dalam diskusi guna mendapakan pemcahan masalah maupun keluasan wawasan. Keterbukaan merupakan lanjutan dalam bersikap jujur. Tabiat terbuka bertujuan pada penghindaran interkasi negative, saling mencurigai. Hal demikian bisa dikecualikan pada persoalan dan permasalahan yang seharusnya tidak dilontarkan kepada public dan terbatas untuk pertimbangan keamanan dan ketentraman bersama. Keterbukaan inilah pemelihara kohesifitas sekaligus pengawasan dari perjalanan roda organisasi.(Hattani 2014; PP. 


\section{LAKPESDAM NU 1992)}

\section{Al-Amanah wal-Wafa bil 'ahd}

Prinsip ini berisi dua sifat atau sikap yang saling berkaitan, yakni alamanah dan al-wafa' bil 'ahdi. Keduanya, secara sendiri ataupun bersama, engarah pada arti kejujuran atau as-sidq, yaitu tingkat kepercayaan yang tinggi dari pihak yang lain. Seseorang yang dapat dipercaya, setia dan tepat dalam janji sehingga menjamin integritasnya saat melaksanakan wewenang dan menjalankan tugas. Meski demikian semuanya menjadi satu syarat penting dalam kesepakatan dan kerjasama dengan berbagai kelompok dan golongan. istilah amanah yang pertama bermakan lebih umum dari pada istilah kedua. Di dalamnya meliputi semua tugas, beban, kerja yang harus dilaksanakan, baik ada perjanjian maupun tidak. al-wafa' bil 'ahdi bermakna lebih spesifik pada perbuatasan dan aktivitas yang telah ditetapkan perjanjian sebelumnya. Kedua istilah tak bisa dipisahkan karena kedudukan seseorang adalah mukallaf. Kapasitas itu mengharuskan seseorang untuk berdedikasi dalam pelaksanaan semua perjanjian, baik perjanjian yang dibuat maupun yang melekat. kontrak sosial yang disepakati antar sesama anggota masyarakat, perjanjian dalam kepemimpinan terhadap bawahan dipimpin, atau ucapan janji kepada kerabat keluarga termasuk setiap individu yang lain. Perbuatan ingkar yang menyimpang dari janji dikategorikan dalam nifaq.(Hartono dan Lutfauziah 2012; Hattani 2014)

\section{Al-'Adalah}

Mabda' ketiga telah mendorong orang berpegang kepada obyektifitas sehingga bisa memposisikan semua hal sesuai porsinya. Sikap ini harus ditegakkan ketika perkaranya menyangkut perselisihan dengan berbagai pihak. Seseorang yang berkeadilan selalu berpijak pada ukuran obyektifitas, proposional dan ketaatan terhadap asas. Prinsip demikian telah menempatkan rasionalitas berkewahyuan berada dalam posisi penting dalam pengembilan keputusan. Penyimpangan yang terjadi mungkin diakibatkan dari rasa emosional atau keberpihakan tanpa dasar. Kejadian demikian bisa menjerumuskan dalam kubangan kefatalan. Keputusannya tidak memutuskan tapi malah memperumit rangkaian pemasalahan.(AS 2013; Hartono dan 
Umi Musaropah, Muhamad Mahali, Daluti Delimanugari,

Agus Suprianto, Taufik Nugroho

Lutfauziah 2012; Hattani 2014)

At-Ta'awun

Sikap saling bantu (At-ta'awun) merupakan sifat dasar dalam tata kehidupan manusia dalam bermasyarakat. Sepanjang hidupnya, Ia tak bisa hidup sendiri, mengabaikan pertolongan orang lain. Dalam Islam, Pengertiannya telah dibatasi pada tolong menolong, setia kawan dan gotong royong dalam ketakwaan dan kebaikan di dalamnya ada pengertian timbal balik dari tiap sisi untuk saling memberi dan menerima dalam kerelaan. Sikap itu tidak dalam posisi pasif namun ada motivasi agar berusaha secara kreatif dan kesungguhan untuk memiliki sesuatu yang dapat direlakan bagi sesama termasuk kepentingan bersama. Dengan demikian kegiatan konsolidasi dalam bersikap dan berbuat terhadap sesama adalah pilhan yang terbaik. Pemahaman demikian merujuk kepada pendapat Mawardi ketika menjelaskan pengertian perbuatan baik (al-birr) dengan kerelaan manusia dan taqwa dengan ridla Allah SWT. Memperoleh keduanya berarti memperoleh kebahagiaan yang sempurna.(Hartono dan Lutfauziah 2012; Hattani 2014) Istiqamah

Istiqamah atau keteguhan dalam bahasa Jawa dikenal dengan ajeg-jejeg. Maksudnya adalah berketeguhan, berkesinambungan, dan berkelanjutan. Yang pertama bermakna, Perlakuannya tetap dan tak bergeser dari ketentuan Allah, tuntunan Rasul-Nya, penjelasan dari salafus shalih, termasuk keputusan dan aturan yang telah disepakati secara bersama. Makna kedua atau kata kesinambungan dibaratkan sebuah bangunan yang didalamnya berisi keterkaitan antara satu aktivitas dengan aktivitas lain, juga satu masa dengan masa yang berbeda sehingga membentuk kesatuan utuh yang tak terpisahkan, menopang satu sama lainnya. istilah terakhir adalah berkelanjutan. Di situ proses yang berjalan secara terus menerus tanpa henti. Proses itu bergerak maju tanpa kehendak untuk hanya proses di tempat. (AS 2013; Hartono dan Lutfauziah 2012; Hattani 2014)

\section{Implementasi dalam Tridarma Perguruan Tinggi}

Dengan visi yang dimiliki dan orientasi kebangsaan yang telah ada dalam Mata kuliah ke-NU-an, seorang mahasiswa usai pendidikan 
diharapkan memiliki beberapa kompetensi bidang kemasyarakatan. Mereka terlibat dalam bidang tridarma perguruan tinggi; pendidikan penelitian dan pengabdian kepada masyarakat.

Pelaksanaan Pembelajaran. Ke-NU-an merupakan salah satu Mata Kuliah Dasar Umum (MKDU) di PAI, maupun STAIYO. Materi Aswaja ini dimaksudkan untuk memfasilitasi kemandirian mahasiswa sehingga trampil memainkan fungsinya sebagai masyarakat yang menjungjung nilai kebangsaan dengan keimanan dalam Islam. mahasiswa bisa bersikap kritis terhadap perosalan dan permasalahan sosial terasah sehingga mampu berpikir secara interdisipliner, dan mampu menerapakan pikiran dan teori para ahli dalam bermasyarakat secara aktif. Semua itu tetap berjalan dalam koridor alMabadi Khoiru Ummah yang cinta tanah air.

Oleh karena itu, proses seleksi dosen pun dilakukan secara hati-hati mengacu kepada kepedulian para dosen dan ikatan kuat mereka dengan lembaga NU yang menaungi nilai-nilai pendidikan STAIYO. Para dosen kemudian dipilih juga pertimbangan keterlibatan mereka secara langsung dengan NU meski dalam tingkat wilayah kota maupun propinsi. Seperti kedua informan dalam penelitian ini. Selain pengajar Aswaja, mereka juga merupakan pengurus aktif NU Kabupaten Gunung Kidul.

Pembelajaran ke-NU-an dibangun berdasarkan perencanaan yang relevan dengan tujuan, ranah belajar dan hierarkinya. berbagai strategi dan teknik yang menantang, mendorong mahasiswa untuk berpikir kritis, bereksplorasi, berkreasi dan bereksperimen dengan memanfaatkan aneka sumber juga digunakan. Sama seperti perkuliahan lainnya juga memiliki mekanisme untuk memonitor, mengkaji, dan memperbaiki secara periodik kegiatan perkuliahan (kehadiran dosen dan mahasiswa), penyusunan materi perkuliahan, serta penilaian hasil belajar.

Dalam Pembelajaran, mahasiswa juga dituntut aktif untuk belajar keNu-an bahkan melalui seni. Karena itu dalam setiap kegiatan termasuk penelitian dan seminar yang diselenggarakan di STAIYO dan PAI selalu mengumandangkan nilai-nilai ke-NU-an sebelum acara di mulai. Setelah mengumandangkan Indonesia Raya, lagu mars NU -Ya Lal Waton- yang 
Umi Musaropah, Muhamad Mahali, Daluti Delimanugari,

Agus Suprianto, Taufik Nugroho

selalu dikumandangkan. Syairnya jelas sekali menyerukan kebanggaan dan kecintaan terhadap Indonesia.

ya lal watan $3 x$

Hubbul Watan minal Iman

Wala Takun minal Hirman

Inhadu ahlal watan.

Indonesia biladi

Anta 'unwanul fakhama

Kullu man ya'tika yauman

Tamihan yalqa himaman

Pusaka Hati Wahai Tanah Airku

Cintamu dalam Imanku

Jangan Halangkan Nasibmu

Bangkitlah Hai Bangsaku

Pusaka Hati Wahai Tanah Airku

Cintamu dalam Imanku

Jangan Halangkan Nasibmu

Bangkitlah Hai Bangsaku

Indonesia Negeriku

Engkau Panji Martabatku

Siapa Datang Mengancammu

Kan Binasa di bawah durimu

Pelaksanaan penelitian. Kepedulian terhadap permasalahan lingkungan, baik terhadap lingkungan sosial, ekonomi, ekologi, politik dan budaya, itu adalah kewajiban utama dari para cendikiawan. khususnya cendekiawan Muslim (intelektual Islam), sebagai bukti perwujudan dari nilai dasar MKU, seruan kepada kebaikan dan pencegahan dari keburukan. Kajian filsafat pendidikan Islam dan PAI secara akademis di kampus STAIYO, Gunung Kidul tidak boleh hanya sekedar menjadi wacana intelektual saja,tetapi disamping itu setiap dosen dan mahasiswa harus mampu mandiri dalam menghadapi persoalan kemanusiaan dan lingkungan.

PAI juga mempunyai arah penelitian dengan kegiatan penelitian, seminar tentang peran agama dalam isu-isu pendidikan Islam maupun umum, yang diikuti dengan publikasi di media massa, berupa artikel dan penerbitan buku-buku, acara TV dan radio, diskusi di jagat maya (internet), d1l. Semuanya adalah dalam rangka proses pencerahan pemikiran dan 
pembangunan kesadaran baru masyarakat ke arah peradaban yang lebih baik dan progresif.

Selanjutnya bapak Samin menjelaskan Peran pendidikan ke-NU-an di masyarakat sangat penting, karena mendukung PAI sebagai bekal utama bagi umat manusia terutama umat Islam sehingga dapat bermanfaat untuk mengembangkannya, dan dapat memberikan solusi reformasi dan restorasi secara baik dan benar. Dengan ketajaman analisis rasional yang diperkuat secara sinergis dengan ketajaman intuisi dan bimbingan wahyu ilahiyah, maka tanggapan yang dapat dilakukan terhadap berbagai problem kemanusiaan dan lingkungan dapat diberikan sesuai bimbingan ilahiyah Ketuhanan Yang Maha Esa.

Diantara penelitian dosen yang melibatkan mahasiswa yang berkaitan dengan isu-isu pesantren NU dan kebangsaan adalah; Musaropah (2019) tentang Pendidikan Kebangsaan Dalam Pesantren Perspektif Abdul Wahid Hasyim atau Kharisma Kyai Dalam Organisasi Pendidikan Pesantren Tradisional (Musaropah 2018); Delimanugari (2018) Pengembangan Media Permainan Ilmu Pengetahuan Alam untuk Meningkatkan Minat dan Hasil Belajar MI/ SD di Gunung Kidul Jogjakarta; Mengembangkan literasi informasi melalui belajar berbasis kehidupan terintegrasi PBL untuk menyiapkan calon pendidik dalam menghadapi era revolusi industri 4.0 (Mintasih 2018) Pengembangan Bahan Ajar Berorientasi KKNI Untuk Penguatan Scientific Approach Pada Mata Kuliah Evaluasi Dan Proses Pembelajaran Pendidikan Agama Islam (Mintasih 2017). Ria Nurhayati, Pendidikan Karakter dari Sri Sultan Hamengku Buwana IX; Muhammad Agus Najib, Kontekstualisasi Pendidikan Pancasila dan Kewarganegaraan di Tengah Ancaman Perpecahan Atas Nama SARA; Muhammad Agus Najib, Nilai nilai Pendidikan Spiritual dalam Majelis Shalawat Hubbin Nabi di Gunung Kidul; Khoirul Anam, dkk, Menimbang Sistem Pemilihan Presiden secara Langsung di Indonesia tahun 2009 Perspektif Siyasah Syar'iyah. Kosmologi Islam Pesisir Gunung Kidul (Mengungkap Corak, Praktek dan Ritual Keagamaan Asli Masyarakat Islam Pesisir ditinjau dari Nilai-Nilai Islam) (Suprianto dan Anam 2016) 
Umi Musaropah, Muhamad Mahali, Daluti Delimanugari,

Agus Suprianto, Taufik Nugroho

Pengabdian kepada Masyarakat. Sebagai bukti bahwa seluruh civitas akademika STAIYO termasuk mahasiswa begitu perduli dengan masalah kemasyarakatan termasuk lingkungan dan kemanusiaan, maka contoh perilaku kecendekiawanan dari segenap civitas akademika STAIYO, Gunung Kidul itu dapat digambarkan dari berbagai kegiatan yang telah djalankan. Salah satu publikasinya adalah Pengembangan Kewirausahaan Berbasis Industri Kreatif Bagi Jamaah Wanita Majelis Taklim Di Desa Kepek (Musaropah et al. 2019).

Dalam penyelenggaraannya mereka tidak sebatas melibatkan masyarakat sekitar. Lajnah PT NU juga sering menjadi mitra langsung dalam kegiatan-kegiatan pengabdian kepada masyarakat yang dijalankan. Pembentukan dan pendampingan desa binaan dalam menjalankan kehidupan beragama, pendidikan dan kesehatan serta pembentukan keluarga Islam yang sakinah mawadah warahmah. Pengabdian juga dilakukan pengembangan Korp Dakwah Islamiyah yang melibatkan dosen dan mahasiswa. mereka diturunkan ke desa desa untuk memberikan pengajian, melakukan bakti social dan pmeberian santunan kepada masyarakat miskin dan kelompok usia jompo.

Kegiatan tanggap bencana yang menggerakan mahasiswa untuk memiliki rasa peduli terhadap korban bancana serta melakukan tindakan reflektif dengan pembentukan tim tanggap bencana serta melakukan tindakan nyata dengan mengoptimalkan peran dan program tanggap bencana melalui tim dan satker tanggap bencana STAI Yogyakarta. Kegiatan nyata itu diantaranya : kegiatan penggalangan dana untuk peduli korban bencana, pemulihan mental korban bencana secara individual seperti dengan pendekatan konseling empatik dan penyuluhan tanggap bencana dalam bentuk kelompok dan masal.

Kegiatan yang menonjol dan rutin diaksanakan dalam pengabdian masyarakat bersama mahasiswa adalah Kuliah Kerja Nyata. Pengabdian masyarakat yang dilakukan oleh mahasiswa STAIYO, Gunung Kidul Prodi PAI adalah pengabdian yang berbasis keilmuan dan edukasi. Mahasiswa PAI STAIYO, Gunung Kidul dilibatkan mulai dari merumuskan kegiatan, 
membuat jadwal pengabdian sampai kepada pelaksanaan pengabdian masyarakat. dengan cara seperti ini, maka mahasiswa mampu menjadi manusia yang tanggap terhadap lingkungannya namun tidak keluar dari berbagai macam teori yang dipelajari dan dikuasai. Dengan demikian, maka pengabdian kepada masyarakat yang dilakukan oleh mahasiswa PAI STAIYO, Gunung Kidul benar-benar dijiwai oleh keilmuan dan kebersamaan di antara berbagai macam pihak.

\section{Penutup}

Tingkat partisipasi mahasiswa dan seluruh sivitas akademika STAIYO, Gunungkidul sangatlah tinggi hal ini disebabkan karena mereka menyadari bahwa di kemudian hari mereka akan menjadi tokoh masyarakat yang harus mengayomi dalam nalar agama berkebangsaan NKRI. sebagai calon guru-guru profesional mereka nantinya akan dipakai rujukan oleh masyarakat tentang berbagai macam hal yang terkait dengan persoalan social. oleh karenanya, mereka membekali diri dengan berbagai macam ilmu pengetahuan serta mempersiapkan mental untuk bisa mengabdi kepada masyarakat. bahkan sudah banyak mahasiswa STAIYO yang menjadi tokoh masyarakat karena selain kuliah mereka juga menjadi guru mengaji, penceramah agama maupun guru di berbagai lembaga baik yang ada di bawah naungan diknas maupun kemenag. Contoh atau wujud dari pengabdian masyarakat tersebut seperti melakukan pendidikan politik kepada masyarakat, melakukan PKL di berbagai sekolah, memberikan ceramahceramah keagamaan kepada masyarakat maupun melakukan bakti sosial.

\section{Daftar Pustaka}

Alfin, Miftachul, dan Fattah Setiawan Santoso. 2013. "Strategi Pengembangan Perguruan Tinggi Agama Islam Sebagai Organisasi Pembelajaran." Ulumuddin: Jurnal Ilmu-ilmu Keislaman 3(2):54-67.

AS, A. Sunarto. 2013. "Paradigma Nahdlatul Ulama Terhadap Modernisasi." Jurnal Sosiologi Islam 3(2, Oktober 2013):51-74.

Delimanugari, Daluti. 2018. "Pengembangan Media Permainan Ilmu Pengetahuan Alam untuk Meningkatkan Minat dan Hasil Belajar MI/ SD di Gunung Kidul Jogjakarta." FONDATIA 2(2):117-35. doi: 10.36088/fondatia.v2i2.130.

Fauroni, Lukman, M. Rusydi, Maftukhatusolikhah Maftukhatusolikhah, dan 
Umi Musaropah, Muhamad Mahali, Daluti Delimanugari,

Agus Suprianto, Taufik Nugroho

Nur Mukhlis Zakaria. 2019. "Pengembangan Wawasan Islam Kebangsaan Mahasiswa Melalui Konseling Sebaya di Masjid Kampus." Nuansa Akademik: Jurnal Pembangunan Masyarakat 4(2):105-16.

Hartono, Djoko, dan Asmaul Lutfauziah. 2012. NU dan ASWAJA Menelusuri Tradisi Keagamaan Masyarakat Nahdliyin di Indonesia. Surabaya: Ponpes Jagad 'Alimussirry.

Hattani, M. Bisri Adib, ed. 2014. Khittah dan Khidmah Nahdlatul Ulama. Pati: Majma' Buhuts An-Nahdliyah (Forum Kajian Ke-NU-an).

Lickona, Thomas. 2013. Education For Character: How Our School Can Teach Respect And Responsibility. Jaka: Bumi Aksara.

Mintasih, Diyah. 2017. "Pengembangan Bahan Ajar Berorientasi Kkni Untuk Penguatan Scientific Approach Pada Mata Kuliah Evaluasi Dan Proses Pembelajaran Pendidikan Agama Islam ." Journal Al-Manar 6(1). doi: 10.36668/JAL.V6I1.24.

Mintasih, Diyah. 2018. "Mengembangkan literasi informasi melalui belajar berbasis kehidupan terintegrasi PBL untuk menyiapkan calon pendidik dalam menghadapi era revolusi industri 4.0." ELEMENTARY: Islamic Teacher Journal 6(2):271-90.

Musaropah, Umi. 2018. "Kharisma Kyai Dalam Organisasi Pendidikan Pesantren Tradisional." Ulumuddin: Jurnal Ilmu-ilmu Keislaman 8(2):14155.

Musaropah, Umi. 2019. "Pendidikan Kebangsaan Dalam Pesantren Perspektif Abdul Wahid Hasyim." Ulumuddin: Jurnal Ilmu-ilmu Keislaman 9(1):1-22. doi: 10.47200/ulumuddin.v9i1.284.

Musaropah, Umi, Suharto Suharto, Daluti Delimanugari, Agus Suprianto, Rubini Rubini, Retno Kurnianingsih, dan Citra Ayudiati. 2019. "Pengembangan Kewirausahaan Berbasis Industri Kreatif Bagi Jamaah Wanita Majelis Taklim Di Desa Kepek." Nuansa Akademik: Jurnal Pembangunan Masyarakat 4(2):79-90.

PP. LAKPESDAM NU. 1992. Keputusan Musyawarah Alim Ulama NU 1992 No. 04/Munas/1992 Tentang Mabadi Khaira Ummah.

Suprianto, Agus, dan Khoirul Anam. 2016. "Kosmologi Islam Pesisir Gunung Kidul (Mengungkap Corak, Praktek dan Ritual Keagamaan Asli Masyarakat Islam Pesisir ditinjau dari Nilai-Nilai Islam)." Mukaddimah: Jurnal Studi Islam 1(1):119-52. doi: 10.14421/MJSI.11.1337.

Syafiyana, Ika Nur. 2015. "Manajemen Sumber daya Pendidik dan Tenaga Kependidikan di Sekolah Tinggi Agama Islam Yogyakarta (STAIYO) (Analisis Proses Rekrutmen dan Pengembangan Profesionalitas Dosen dan Tenaga Kependidikan)." UIN Sunan Kalijaga Yogyakarta.

Tim Penyusun. 2010. Naskah Akademik UM The Learning University. Malang. Tim STAIYO. 2015. Profil STAIYO Wonosari. Wonosari: STAIYO. 